\title{
Karsten Giese et Laurence Marfaing (éds). Entrepreneurs africains et chinois. Les impacts sociaux d'une rencontre particulière
}

Dirk Kohnert

\section{CpenEdition}

\section{Journals}

Electronic version

URL: http://journals.openedition.org/anthropodev/555

DOI: 10.4000/anthropodev.555

ISSN: 2553-1719

\section{Publisher}

APAD - Association pour l'anthropologie du changement social et du développement

\section{Printed version}

Date of publication: 1 May 2017

Number of pages: 149-152

ISBN: 979-10-93476-04-9

ISSN: 2276-2019

\section{Electronic reference}

Dirk Kohnert, « Karsten Giese et Laurence Marfaing (éds). Entrepreneurs africains et chinois. Les impacts sociaux d'une rencontre particulière », Anthropologie \& développement [Online], 45 | 2017, Online since 01 October 2017, connection on 24 September 2020. URL : http://journals.openedition.org/anthropodev/ 555 ; DOI : https://doi.org/10.4000/anthropodev.555

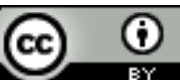

La revue Anthropologie \& développement est mise à disposition selon les termes de la Licence Creative Commons Attribution 4.0 International. 


\section{Entrepreneurs africains et chinois Les impacts sociaux d'une rencontre particulière}

Karsten Giese et Laurence Marfaing (éds), 2016, Paris, Karthala, 384 p.

Dirk Kohnert

In view of early prejudices about the passive or even disapproving reception of Chinese migrants by Africans, the state of the art underlines the importance and scope of African agency vis-à-vis Chinese migrant entrepreneurs in Africa. This has been underlined also by this volume, edited by Laurence Marfaing and Karsten Giese. They document an on-going research project which started six years ago at the German Institute of Global and Area Studies (GIGA-Hamburg) and combines African and Sinologist perspectives. It is published in French. This can be seen both as an advantage and a disadvantage. Considering the lack of French edited publications on this subject and the deplorable language divide between Anglophone and Francophone Africa, the chapters (some of them translated from English) are certainly very welcomed by French speaking African readers and scholars alike. Thus, they have the opportunity to become familiar with the results of painstaking studies by cutting-edge researchers. Some of the contributions are revised papers originally presented at a workshop in Dakar organized by the editors in January 2013 within the framework of the program Point Sud, an International Centre for Research on Local Knowledge in Bamako (Mali).

The introduction by the editors, written jointly with their research collaborator, Alena Thiel, develops the leitmotiv of the book. It aptly captures the essence of the research findings presented in its title: "From rejecting the other to mutual involvement of both parties in the dynamics of social change" (p.7). In fact, the relations of Chinese and African petty traders and their mutual perception have changed fundamentally since the xenophobe manifestations against 'the Chinese' in several African towns as well as mutual incomprehension of both in Chinese towns (mostly in the urban districts Xiaobei and Sanyuanli of Guangzhou) where migrant African entrepreneurs arrived in the early 2000s. Many, if not most of them, did not come to stay in the host country permanently, but they acted rather as sojourner, exploring the terrain in search of profitable trade, i.e. Chinese imports of cheap consumer goods to Africa. Their mutual economic interest was based on the development of Chinese industrial production that facilitated Africans access to the desired Western products at an affordable price (p.14-15). Thus, these entrepreneurial migrants, who incorporated globalization from below in their very transnational economic practices, became themselves carriers of social and economic transformations in their respective host countries. The realm of these transformations covered a remarkable range, from specific access-strategies to 
resources and social mobility, changing consumer behaviour, new norms and practices up to modifications of taste and ways of life (p.16).

The editors divided the volume in three parts, using the concept of the construction of 'the other' as a pivot. First, 'the other elsewhere', opportunities of social mobility; second, encounters, stimuli for social change; and third, the production of the 'other', the 'Made in China' as social image and opportunity. Beside China, the case studies concentrate on West African capitals (Accra, Dakar, Niamey, Ouagadougou) and South Africa.

Katy Lam analyses how and why three different types of Chinese citizens became entrepreneurs in Accra, using licensed representatives or employees of Chinese state enterprises formerly working in Ghana, as well as women entrepreneurs and partners of businessmen of the local elite as examples. Their social mobility was interrelated with the articulation of social transformations in China and remained fragile despite undeniable opportunities for social and economic advancement. The same holds for Chinese woman entrepreneurs in Niamey, studied by Naima Topkiran, who practice circular migration, being economicaly active and guarding their transnational family contacts both in their host country and at home. Their migration allowed for better living conditions and greater gender autonomy, thus initiating socio-cultural change in gender relations as well. Cultural mediation between the two worlds, Chinese and African, just as between formal and informal spheres of globalization in their local shape, is the focus of the contribution of Gordon Mathews who describes why and how certain Africans in Southern China act as intermediaries and facilitators of transnational commerce. Favoured by their affiliation to the cultural elite at home, they actively sought the confidence of their Chinese counterparts and were often accepted as a legitimate part of the mosaic of Chinese culture.

But social advancement is apparently not restricted to the well-to-do, as a case studied by Kelly Si Miao Liang shows in her opening of second part of the book. Two underprivileged groups, i.e. African petty wholesale buyers and Chinese migrant workers living side by side in a suburb of Canton, serve as an example. Their intercultural encounter opened-up new realms of reasonable expectations for social promotion. Karsten Giese continues in raising the crucial question of agency concerning observed social innovations in West African trade relations. Chinese migrant entrepreneurs in Accra and Dakar appeared at the same time as employer and commercial partners of their African counterparts, e.g. mobile women hawkers, belonging to the most underprivileged class in Ghana. They allowed the hawkers, to whom they sold some of their goods, to resell it in the open space before their shops. In doing so, the Chinese provided them with a secured space and new income earning possibilities, with due regard to the Chinese's own 
advantage, because they themselves profited from the low cost extension of their sales area thereby winning a competitive edge vis-à-vis Ghanaian competitors. Largely unwittingly, the Chinese merchants, who did not bother about the consequences of their lack of knowledge of local customs, norms and practices, facilitated micro innovations of social change, guided by the agency of their African counterparts. Subsequently, Ben Lampert and Giles Mohan show in their comparative case-study that local agency and class policy are central determinants of socio-economic transformation induced by the growing presence of Chinese migrant entrepreneurs, in Ghana (about 20,000 in 2010) and Nigeria $(150,000)$. Although the percentage of African actors who benefit from the Chinese presence was still limited, African agency from below profiting from this presence could develop under certain conditions into social and economic change of 'revolutionary' proportions in the host country. Local agency as expressed in class politics plays a key role in this respect because most often the political and economic local elites profit most, sometimes to the detriment of other local interest. Apparently, the Chinese presence in Africa does not necessarily result in win-win situations for everyone. This is underlined also by Amy Niang's study of developments in Senegal, where established local operators readily admitted that the Chinese could serve as model for ambitious new and younger entrepreneurs. However, as a rule this worked only to the detriment of the prerogatives of established clientelist business networks which bitterly opposed the intruders by fomenting growing xenophobia.

The third part of the book is focused not on Chinese-African relations but on the social and economic impact of the growing presence of Chinese products, imported by Chinese and Africans alike, on African markets. Guive Khan Mohammad shows that the capture of the Burkina Faso market by motorbikes made in China resulted in almost revolutionary changes. The massive influx of motorcycles provoked not just a restructuration of the import sector from European and Japanese to cheaper Chinese bikes but also the entrance of a new generation of African small and medium enterprises and entrepreneurs (parkeurs, emballeurs, colleurs, laveurs de motos, etc.), notably in the distribution and repair network. Moreover, the low-cost bikes created increased mobility for certain sectors of service and commerce, including adapted local consumer habits (e.g. brigades mobiles) and delivery networks (e.g. taxi-bagages). Thus, the extra mobility contributed also to improved transport connections in the countryside and in general it allowed African actors to hold their ground vis-à-vis the upheavals created by globalization. No wonder then, that 'Made in China' opened new horizons and influenced the dreams of Africans of an alternative way of development from the European model. Many of the respondents interviewed by Laurence Marfaing in Senegal thought it easier nowadays to earn ones living in 
China than in Europe to which the channels of migration are progressively closing. With its ready-made and cheap copies China 'demystified Europe' as one of her interlocutors put it (p.337). Certainly, China has become an alternative model. However, it is not a model which could be exactly copied. African petty traders investigated by Marfaing in Guangzhou (Canton) for example realized that they would have to find their proper model of development, different from that of the Chinese and the Europeans. Thus China continued to serve as a kind of springboard for a number of young African entrepreneurs both in the acquisition of expertise and professionalism as well as of social and financial capital. It allows for a way of life other than the Western style, but nevertheless gives a promising possibility of African participation in the process of globalization. Finally, Alena Thiel shows in her study of the market of chinese-made products in Accra how the image of 'authentic', but in reality falsified products, has been utilized in the public discourse of vendors and buyers alike in their permanent negotiations about product quality and value. Whereas African transnational traders occupy their corner of the market captured from their Chinese competitors by obscuring the Chinese origin of their products in pretending to offer the fashionable original (Western) design, potential buyers evoke connotations of contraband, fake, and low quality in order to get a bargain.

All in all, the volume gives an impressive, evidence based scholarly overview of the many facets of the Chinese-African encounter both in African capitals as well as in the central wholesale and retail outlets of products made in China. It incorporates painstaking case studies, not just of commercial transactions and business relations, but also of its repercussions for the transformation of local economic structures and social relations. Thus, it constitutes an outstanding net value added to the ongoing international discussion and opens up promising prospects for Africans who, due to their proper agency from below, find their place in the process of globalization. One might deplore the lack of english summary to each case though. It would have enhanced international comprehension. 